\title{
KLASIFIKASI AROMA TEMBAKAU MENGGUNAKAN LEARNING VECTOR
}

\section{QUANTIZATION}

\author{
M. Nurul Arif, Misbah, Yoedo Ageng Surya. \\ Universitas Muhammadiyah Gresik \\ Jl.Sumatera No. 101 GKB, gresik \\ E-mail:arifwidiyanto750@gmail.com,misbah@domain, mryoedo@gmail.com
}

\begin{abstract}
ABSTRAK
Aroma tembakau ditentukan oleh kandungan gas-gas atau jumlah campuran bahan organik yang mudah menguap dan tidak mudah menguap. Proses penentuan sebelumnya telah di lakukan dengan metode analistis konvensional,yang melibatkan kombinasi antara manusia dan instrumentasi sekala besar. Metode ini sangat mahal dalam kaitannya dengan waktu dan tenaga kerja, karena membutuhkan peralatan yang sangat komplek dan tingkat ketelitian dari analisa yang di lakukan oleh ahli tembakau pada saat tertentu, karena indra penciuman ahli tembakau menjadi sangat rendah pada saat tertentu. karena indra penciuman manusia sangat tergantung pada kelembaban, suhu dan kondisi fisik. Oleh sebab itu di buatlah alat yang dapat mendekati dari hasil penciuman para ahli tembakau. Dengan mengalirkan gas yang di hasilkan tembakau ke sensor untuk dideteksi dan di lakukan proses sinyal analog menjadi sinyal digital (ADC). Setelah proses ADC, data akan di kirim ke pc melalui komunikasi serial untuk di lakukan proses pelatihan neural network menggunakan learning vector quantization untuk menentukan bobot dari jaringan neural network kemudian hasil dari pelatihan digunakan untuk klasifikasi tembakau yang diterima dan ditolak. Dari hasil pengujian sistem ini dapat mengidentifikasi tembakau yang diterima dan tembakau yang ditolak dengan tingkat ke akuratan $93,3 \%$.
\end{abstract}

\section{Kata kunci: klasifikasi tembakau menggunakan learning vector quantization}

\section{PENDAHULUAN}

Tembakau merupakan bahan baku utama untuk pembuatan rokok. Sehingga kualitas dari tembakau tersebut sangat berpengaruh langsung pada kualitas rokok tersebut. Salah satu dari penentuan kualitas tembakau itu dari aroma. Dalam aroma tembakau banyak terkandung berbagai macam zat kimia yang bersifat volatile dan non volatile. Untuk mengetahui zat kimia tersebut biasanya menggunakan teknologi krimatografi gas.

Petani banyak yang belum bisa menentukan kualitas tembakau sehingga para petani ini menyetorkan hasil panennya ke pengepul, kemudian dari pengepul menguji tembakau tersebut. Setelah di uji kemudian tembakau diseleksi, tidak jarang hasil panen mereka banyak yang dikembalikan sehingga berdampak kerugian bagi spetani pada transpotasi dan biaya kuli panggul untuk menyetorkan tembakau.
Maka dalam penelitian ini diambil judul "Klasifikasi Aroma Tembakau Menggunakan LearninVector Quantization". Pada alat ini menggunakan sensor gas MQ4, MQ7, MQ135 dan MQ137 untuk mendeteksi kandungan tembakau learning vector quantization mengenalkan mikrokontroler terhadap klasifikasi aroma dari tembakau.

\section{LANDASAN TEORI TEMBAKAU}

Tembakau adalah produk pertanian yang diproses dari daun tanaman. Pada umumnya tembakau di buat menjadi rokok, tembakau kunyah dan juga dapat di gunakan sebagai obat dalam bentuk nikotin tartrat. Selain itu terbakau di bidang pertanian di buat menjadi pestisida. Tembakau telah lama di gunakan sebagi entheogen di amerika. Kedatangan bangsa eropa ke amerika utara mempopulerkan perdagangan tembakau sebagai obat penenang. Tembakau mengandung komponen volatile sebanyak 300 
macam yang berperan dalam memberikan cita aroma khas pada tembakau. Diantaranya adalah protein, nikotin, pati, polypenol, magnesium $(\mathrm{Mg})$, calcium $(\mathrm{Ca})$, phosphor $(\mathrm{P}), \mathrm{Zn}$, potassium, $\mathrm{Cu}$ dan lainnya (Rivai, 2011). Tanaman tembakau merupakan salah satu tanaman tropis amerika, di mana bangsa pribumi menggunakannya dalam upacara adat dan untuk pengonbatan (Basyir, 2006).

Sensor MQ (MQ4, MQ7, MQ135, MQ137)

Tabel`1 sensor yang digunakan

\begin{tabular}{|l|l|}
\hline sensor & Sensivity to \\
\hline MQ4 & Natural gas, Methane \\
\hline MQ7 & Karbon Monoksida (CO) \\
\hline MQ135 & $\begin{array}{l}\text { Air Quality Control } \\
\text { (NH3,Benzene,Alcohol,Smoke) }\end{array}$ \\
\hline MQ137 & Ammonia \\
\hline
\end{tabular}

\section{Learning Vector Quantization (LVQ)}

Suatu metode untuk melakukan pembelajaran pada lapisan kompetitif yang terawasi. Suatu lapisan kompetitif akan secara otomatis belajar untuk mengklasifikasikan vektorvektor input. Kelas-kelas yang didapatkan sebagai hasil dari lapisan kompetitif ini hanya tergantung pada jarak antara vektor-vektor input. Jika dua vektor input mendekati sama, maka lapisan kompetitif akan meletakkan kedua vektor input tersebut ke dalam kelas yang sama. (Kusumadewi,2003). Pada gambar ditunjukkan arsitektur LVQ yang digunakan pada penelitian ini.

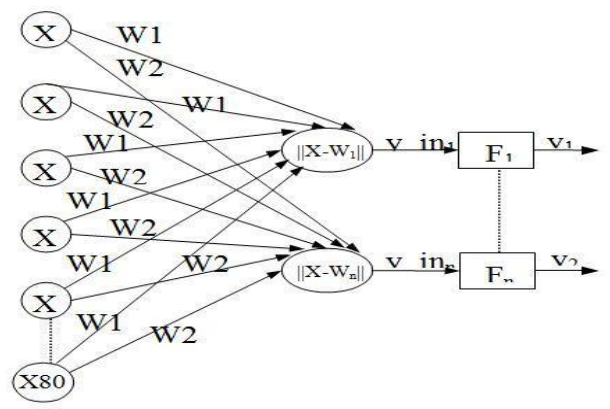

Gambar 1 Arsitektur Jaringan LVQ

Pada jaringan LVQ, pembelajaran atau pelatihan jaringan harus dilakukan terlebih dahulu. Pembelajaran akan menyesuaikan bobot denganpola-pola yang dipelajari dari data. Algoritma pembelajaran LVQ dapat dilihat sebagaiberikut (Kusumadewi,2003) :
0. Tetapkan : a. Bobot awal variable input ke-j
menuju kekelas (cluster) ke-i:

Wij, dengani $=1,2, . ., \mathrm{K} \quad ; \quad$ dan $\mathrm{j}=1,2, . ., \mathrm{m}$.

b. Maksimum epoh: MaxEpoh.

c. Parameter learning rate: $\alpha$.

d. Pengurangan learning rate:Dec $\alpha$.

e. Minimal learning rate yang diperbolehkan: Min. $\alpha$.

1. Masukkan:
a. Data
input
:Xij;
dengani $=1,2, . ., n$; dan $j=1,2, . ., m$.
b. Target berupakelas : Tk; dengan $\mathrm{k}=1,2, \ldots, \mathrm{n}$.

2. Tetapkan kondisi awal: epoh=0

3. Kerjakan jika: (epoh $\leq$ MaxEpoh) dan $(\alpha$ $\geq \operatorname{Min} . \alpha$ )

a. Epoh $=$ epoh +1

b. Kerjakan untuk i=1 sampai $n$

a) Tentukan $\mathrm{J}$ sedemikian hingga $|\mathrm{Xi}-\mathrm{Wj}|$ minimum; dengan $\mathrm{j}=1,2, . ., \mathrm{K}$.

b) Perbaiki $\mathrm{Wj}$ dengan ketentuan :

Jika $\mathrm{T}=\mathrm{Cj}$, maka $\mathrm{Wj}=$ $\mathrm{Wj}($ lama $)+\alpha(\mathrm{Xi}-\mathrm{Wj})$ Jika $\mathrm{T} \neq \mathrm{Cj}$, maka $\mathrm{Wj}=$ $\mathrm{Wj}($ lama $)-\alpha(\mathrm{Xi}-\mathrm{Wj}) \quad(2.2)$

c. Kurangi nilai $\alpha$.(Pengurangan $\alpha$ bisa dilakukan dengan $: \alpha=\alpha$ Dec $\alpha$; atau $\alpha=\alpha *$ Dec $\alpha$ ).

4. Tes kondisi berhenti dengan,

$\mathrm{X}$ vektor-vektor pelatihan $(\mathrm{X} 1, \ldots \mathrm{Xi}, \ldots \mathrm{Xn})$.

$\mathrm{T}$, kategori atau kelas yg benar untuk vektor-vektor pelatihan $\mathrm{Wj}$, vektor bobot pada unit keluaran ke-j (W1j,...Wij,...,Wnj).

$\mathrm{Cj}$, kategori atau kelas yang merepresentasikan oleh unit keluaran kej. $\|\mathrm{x}-\mathrm{wj}\|$, jarak Euclidean antara vektor masukan dan vektor bobot untuk unit keluaran ke-j.

Setelah dilakukan pelatihan akan diperoleh bobotbobot akhir (W) yang mana akan digunakan untuk simulasi atau pengujian. 


\section{METODE}

\section{Pembuatan Sistem}

Perancangan sistem klasifikasi aroma tembakau berdasar bahan campuran menggunakan sensor gas dan metode jaringan syaraftiruan learning vector quantization dibagi menjadi dua bagian yaitu perancangan perangkat keras (hardware) dan perancangan perangkat lunak (software).

\section{Perancangan Hardware}

Perangkat keras terdiri dari modul Arduino Uno versi R3, modul Bluetooth HC-05, Modul LCD 16 x 2, sensor suhu dan kelembapan DHT-11, 4 Modul sensor gas yang berbeda yaitu MQ-4, MQ-7, MQ-135 dan MQ-137 juga beberapa perangkat penunjang sepertifan DC5v sebagai exhaust, rangkaian pembagi tegangan (VCC) serta rangka (cover) yang melindungi seluruh komponen elektrik. Berikut skema kerja sistem:

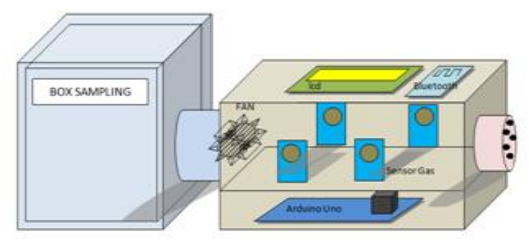

Gambar 2 Rangkaian Sensor Gas dan Sensor Kelembapan

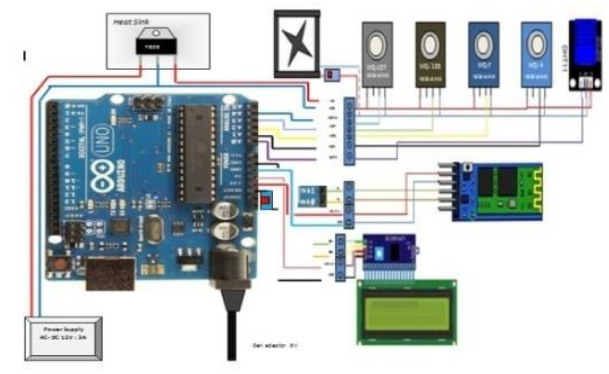

Gambar 3 Rangkaian Keseluruhan Sistem

Pada rangkaian sensor gas dan sensor kelembapan udara (DHT-11) , pin-pin yang digunakan dari setiap sensor hampir sama, yaitu pin tegangan (Vcc) yang mana diberikan $5 \mathrm{~V}$ dan arus 3A yang cukup besar untuk aktivasi sensor (Heating) , Ground (Gnd) dan Digital Output (DO) . Untuk menghubungkan antara sensor ke mikrokontroler Arduino Uno maka pin ouput dari sensor dihubungkan ke pin digital pada arduino uno yaitu pin digital nomer (2-6) seperti gambar rangkaian diatas. Penggunaan mini fan DC $5 \mathrm{~V}$ untuk menyedot gas sampling disambungkan power (Vcc) dan Ground (GND) dari rangkaian sensor ini. Penambahan komponen heat sink pada rangkaian ini perlu dilakukan agar mencegah pemanasan yang berlebih dari power supply melalui regulator.

\section{Perancangan Software}

Pada pembuatan perangkat lunak menggunakan aplikasi Arduino IDE 1.8.5, yang berfungsi sebagai aplikasi programming atau koding dariArduino Uno. Program akan bekerja dengan menganalisa data hasil uji coba dan pemrosesan jaringan saraf tiruan dan menyimpan dalam memori untuk diolah dan diukur pada aplikasi Matlab dan Delphi di PC .

Pada perancangan softwaresistem pengukur kandungan aroma tembakau ini menggunakan bahasa $\mathrm{C}$ sebagai compiler pada Arduino 1.8.5 IDE dan MATLAB 2013 untuk pembuatan software pada $\mathrm{PC}$. Bahasa $\mathrm{C}$ (Coding) pada aplikasi Arduino IDE digunakan untuk membuat program pada flowchart pemrograman mampu mengatur kinerja dari hardware sehingga dapat berjalan sesuai dengan yang diharapkan.

\section{HASIL DAN PEMBAHASAN}

\section{Contoh Sampling Tembakau}

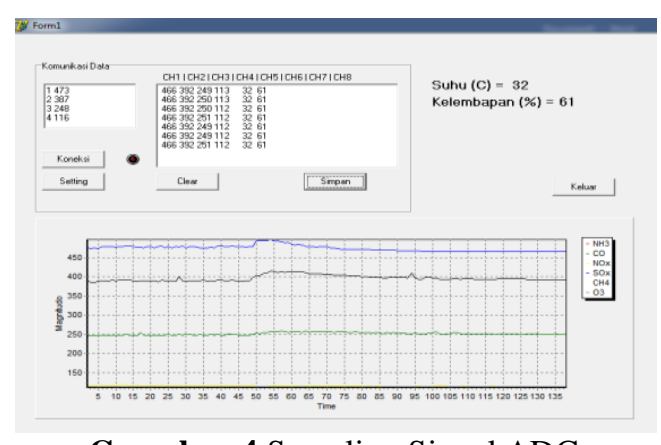

Gamabar 4 Sampling Sinyal ADC

\section{Pengambilan Data Tiap Sensor}

Dalam percobaan pengambilan data sampel dari alat sampling, di peroleh besaran nilai yang berbeda dari tiap sensor, setiap kelas tembakau di lakukan 15 kali pengujian dan ratarata waktu yang di butuhkan untuk mendapat data nilai yang stabil adalah 10 menit ataupun dari program Delphi tersebut lebih dari 130 data.kemudian di catat sehingga di dapatkan 
pembacaastabil sensor yang akan di catat pada ms.exel dan akan di olah pada matlab.

\section{Pengujian alat dengan sampel tembakau}

Berikut adalah pendeteksian aroma dari tembakau yang di uji. Respon pada nilai yang keluar setelah hasil pendeteksian tembakau setelah setabil, maka dapat di tampilkan tembakau kelas 1, kelas 2 dan kelas 3 pada tabel 2 .

Tabel 2 Data rata-rata keseluruhan saat stabil

\begin{tabular}{|c|c|c|c|c|c|c|c|c|c|c|c|c|}
\hline \multirow[b]{2}{*}{ Datavi] } & \multicolumn{4}{|c|}{ kelexs } & \multicolumn{4}{|c|}{ keles? } & \multicolumn{4}{|c|}{ kelas $\}$} \\
\hline & Wol.135 & MOA & ILO" & $101.37^{\circ}$ & MQ135 & I:O4 & MQP" & MQ:137] & Wl(1.135 & 1:O4 & M.Q" & Y:Q1.137 \\
\hline 1 & 400 & 142 & 143 & 573 & 2.66 & 135 & 141 & 600 & 45 & 143 & 141 & 610 \\
\hline 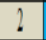 & 394 & 141 & 141 & 572 & 390 & 414 & 14. & 563 & 524 & 156 & 4 & 01 \\
\hline 3 & 499 & 153 & 151 & 665 & 383 & 139 & 142 & 534 & 431 & 148 & 149 & 58. \\
\hline- & 431 & 148 & 1H1 & 610 & 375 & 14. & $\mathrm{HH}$ & 351 & 562 & 110 & 166 & 79. \\
\hline 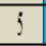 & 368 & 141 & 141 & 612 & 366 & H. & $1 \mathrm{H}$ & 510 & $45 j$ & 149 & $1 \mathrm{H}$ & 645 \\
\hline 6 & 499 & $1 \mathrm{H}$ & 160 & 590 & 368 & 142 & 139 & 500 & 460 & 176 & 153 & 654 \\
\hline 7 & 400 & 153 & 151 & 612 & 388 & 14. & 142. & 489 & 4.2 & 134 & 142 & 700 \\
\hline 8 & 400 & 176 & 143 & 704 & 383 & 139 & 142 & 469 & 432 & 134 & 155 & 780 \\
\hline  & 45 & 143 & 141 & 610 & 32.4 & 135 & 140 & $485^{\circ}$ & 332 & 154 & 140 & 655 \\
\hline 10 & 431 & 148 & 149 & 582 & 324 & 135 & 140 & 485 & $460^{\circ}$ & 145 & 141 & 000 \\
\hline 11 & 562 & 170 & 166 & 99. & 311 & 132 & 137 & 469 & 480 & 149 & 141 & $67 \%$ \\
\hline 12 & 400 & 132 & 153 & 654 & 266 & 131 & 139 & $\mathrm{ANA}$ & 400 & 132 & 143 & 532 \\
\hline 13 & 432 & 134 & 14. & 900 & 3.4 & 134 & 139 & 496 & 499 & $1 \mathrm{H}$ & 160 & 50 \\
\hline If & 36. & 170 & 149 & 582 & 45) & 149 & 148 & 636 & 49 & 141 & 143 & 58. \\
\hline 15 & 49 & 14. & 1.13 & 582 & 373 & $1 \mathrm{H}$ & 1.45 & 569 & $45 !$ & 14. & 139 & 645 \\
\hline
\end{tabular}

\section{Pelatihan data latih}

Berikut hasil data latih aroma dari tembakau yang di uji. Respon pada hasil pendeteksian tembakau pada tabel 3 :

Tabel 3 data latih

\begin{tabular}{|c|c|c|c|c|c|c|c|c|c|c|c|c|}
\hline \multirow{3}{*}{$\begin{array}{l}\text { Data } \\
\text { uij }\end{array}$} & \multicolumn{4}{|c|}{ kelas I } & \multicolumn{4}{|c|}{ kelas? } & \multicolumn{4}{|c|}{ kelas 3} \\
\hline & IIL & IVO & IIQ & IIQ & IIQ & IIQ & IIQ & IIO & IIQ & $\mathrm{IIO}$ & IIQ & IIQ \\
\hline & 135 & 4 & 7 & 137 & 135 & 4 & 1 & 137 & 135 & 4 & 7 & 137 \\
\hline 1 & 400 & 142 & 143 & 573 & 373 & 144 & 145 & 567 & 445 & 143 & 141 & 610 \\
\hline 2 & 394 & 141 & 141 & 572 & 390 & 141 & 142 & 563 & 524 & 156 & 143 & 704 \\
\hline 3 & 479 & 153 & 151 & 665 & 383 & 139 & 142 & 534 & 480 & 149 & 141 & 672 \\
\hline 4 & 431 & 148 & 149 & 582 & 375 & 142. & 144 & 351 & 502 & 170 & 160 & 792 \\
\hline 5 & 368 & 141 & 141 & 612 & 360 & 14l & 144 & 510 & 455 & 149 & 144 & 645 \\
\hline 6 & 479 & 141 & 143 & 582 & 368 & 142 & 139 & 500 & $45]$ & 142 & 139 & 645 \\
\hline 7 & 400 & 153 & 151 & 612 & 383 & 142 & 142 & 489 & 442 & 134 & 142 & 700 \\
\hline
\end{tabular}

Data tersebut nantinya akan di gunakan untuk ditrening dengan menggunakan learning vector quantization seperti pada tabel 3. dari semua data masing masing jenis tembakau di ratarata dengan polanya di gabungkan terlihat terjadi perbedaan pola anatara tembakau berumur 3 minggu, 4 minggu dan 8 minggu. Seperti pada gambar 4 .

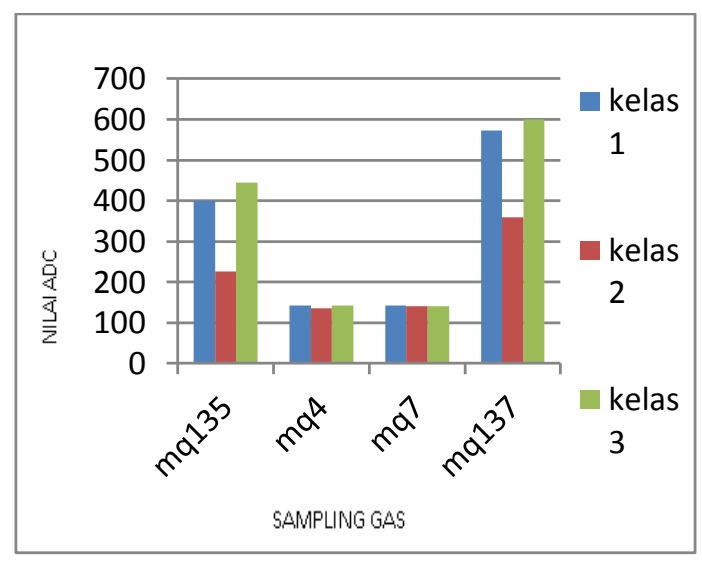

Gamabar 5 pola gabungan tembakau

Tabel 4 data uji tembakau

\begin{tabular}{c|c|c|c|c|c|c|c|c|c|c|}
\hline data ke & benzen & alkohol & co & nh3 & 1 & 2 & 3 & epoch & waktu & peforma \\
\hline 1 & 400 & 142 & 143 & 573 & 0 & & & 89 & 00,21 & 0 \\
\hline 2 & 394 & 141 & 141 & 572 & 0 & & & 60 & 00,14 & 0 \\
\hline 3 & 479 & 153 & 151 & 665 & 0 & & & 102 & 00,24 & 0 \\
\hline 4 & 431 & 148 & 149 & 582 & 0 & & & 43 & 00,10 & 0 \\
\hline 5 & 368 & 141 & 141 & 612 & 0 & & & 32 & 00,07 & 0 \\
\hline 6 & 479 & 141 & 143 & 582 & 0 & & & 44 & 00,12 & 0 \\
\hline 7 & 400 & 153 & 151 & 612 & 0 & & & 34 & 00,11 & 0 \\
\hline 8 & 373 & 144 & 145 & 567 & & $x$ & & 93 & 00,22 & 0 \\
\hline 9 & 390 & 141 & 142 & 563 & & $x$ & & 35 & 00,08 & 0 \\
\hline 10 & 383 & 139 & 142 & 554 & & $x$ & & 65 & 00,15 & 0 \\
\hline 11 & 375 & 142 & 144 & 551 & & $x$ & & 67 & 00,15 & 0 \\
\hline 12 & 366 & 141 & 144 & 510 & & $x$ & & 48 & 00,11 & 0 \\
\hline 13 & 368 & 142 & 139 & 500 & & $x$ & & 78 & 00,13 & 0 \\
\hline 14 & 383 & 142 & 142 & 489 & & $x$ & & 30 & 00,09 & 0 \\
\hline 15 & 445 & 143 & 141 & 610 & & & 0 & 96 & 00,22 & 0 \\
\hline 15 & 524 & 156 & 143 & 704 & & & 0 & 56 & 00,13 & 0 \\
\hline 17 & 480 & 149 & 141 & 672 & & & 0 & 49 & 00,11 & 0 \\
\hline 18 & 562 & 170 & 166 & 792 & & & 0 & 67 & 00,16 & 0 \\
\hline 19 & 455 & 149 & 144 & 645 & & & 0 & 75 & 00,19 & 0 \\
\hline 20 & 451 & 142 & 139 & 645 & & & 0 & 32 & 00,12 & 0 \\
\hline 21 & 442 & 134 & 142 & 700 & & & 0 & 44 & 00,13 & 0 \\
\hline
\end{tabular}

\section{Pengujian dan penentuan kelas pada Matlab}

Dalam pengujian dan penentuan kelas dilakukan dengan memasuk kan data uji tiap-tiap jenis tembakau kedalam kodingan Matlab pada program $\mathrm{x} 1=[479 ; 141 ; 143 ; 582]$; sedang program $\mathrm{y} 1=\operatorname{vec} 2 \operatorname{ind}(\operatorname{net}(\mathrm{x} 1))$ tidak dirubah. 
Kemudian dijalankan dan diamati pada kolom Command Window untuk melihat hasil dari program LVQ tersebut. Setiap percobaan dicatat dan dicari terus menerus dengan merubah parameter hidden layer sampai menemui hasil yang diharapkan dan pastikan pada bagian performance menunjukkan nilai mendekati 0 atau $<0,375$

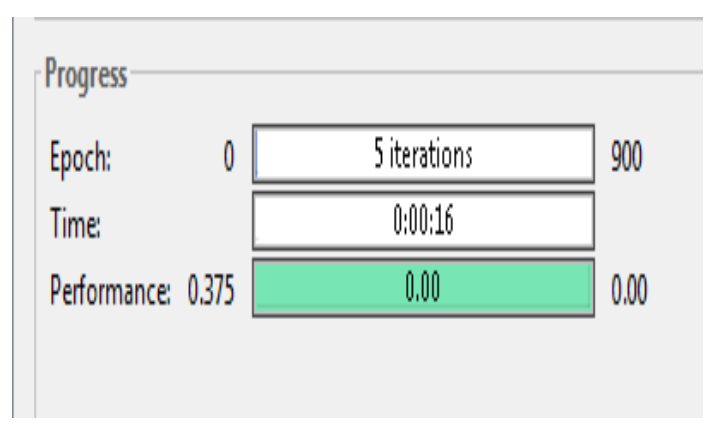

Gambar 6 performance yang sudah sesuai criteria

\section{Hasil Pengujian}

Hasil pengujian dari alat di jelaskan pada tabel berikut:

Tabel 5 Data keseluruhan pengujian kelas 1 (4 minngu)

\begin{tabular}{|c|c|c|c|c|c|c|c|}
\hline \multirow[b]{2}{*}{$\begin{array}{l}\text { Data } \\
\text { yji }\end{array}$} & \multicolumn{3}{|c|}{ Kelas 1 (4 minggy) } & \multirow[b]{2}{*}{ epoch } & \multirow[b]{2}{*}{ waktu (s) } & \multirow[b]{2}{*}{ perfoma } & \multirow[b]{2}{*}{ keterangan } \\
\hline & $\begin{array}{c}1 \\
4 \text { minggu }\end{array}$ & $\begin{array}{c}2 \\
3 \text { minggu }\end{array}$ & $\begin{array}{c}3 \\
8 \text { minggu }\end{array}$ & & & & \\
\hline 1 & 0 & & & 32 & 10 & 0,00 & benar \\
\hline 2 & 0 & & & 32 & 1 & 0,00 & benar. \\
\hline 3 & & $x$ & & 34 & 11 & 0,27 & salab. \\
\hline 4 & & & 0 & 59 & 19 & 0,00 & benar. \\
\hline 5 & 0 & & & 141 & 46 & 0,00 & benar. \\
\hline 6 & 0 & & & 31 & 10 & 0,00 & benar. \\
\hline 7 & 0 & & & 81 & 26 & 0,00 & benar. \\
\hline 8 & & & 0 & 32 & 10 & 0,00 & benar \\
\hline 9 & & & 0 & 32 & 10 & 0,00 & benar. \\
\hline 10 & 0 & & & 34 & 11 & 0,00 & benar. \\
\hline 11 & & & 0 & 59 & 19 & 0,00 & benar, \\
\hline 12 & 0 & & & 141 & 17 & 0,00 & benar. \\
\hline 13 & & & 0 & 31 & 10 & 0,00 & benar. \\
\hline 14 & 0 & & & 81 & 27 & 0,00 & benar \\
\hline 15 & 0 & & & 39 & 13 & 0,00 & benar. \\
\hline
\end{tabular}

Keterangan: Diterima $=0$ Ditolak $=\mathrm{x}$
Tabel 6 Data keseluruhan pengujian kelas 2 (3 minngu)

\begin{tabular}{|c|c|c|c|c|c|c|c|}
\hline \multirow[b]{2}{*}{ Data y } & \multicolumn{3}{|c|}{ Kelas 2 (3minggu) } & \multirow[b]{2}{*}{ epoch } & \multirow[b]{2}{*}{ wakttu (s) } & \multirow[b]{2}{*}{ perfoma } & \multirow[b]{2}{*}{ keterangan } \\
\hline & $14 \mathrm{ming} g \mathrm{u}$ & $23 \mathrm{ming} g \mathrm{l}$ & $38 \mathrm{minggu}$ & & & & \\
\hline 1 & & $\mathrm{x}$ & & 46 & 15 & 0,00 & benar. \\
\hline 2 & & $x$ & & 21 & 7 & 0,00 & benar. \\
\hline 3 & & $x$ & & 54 & 18 & 0,27 & benar. \\
\hline 4 & & $x$ & & 62 & 20 & 0,00 & benar \\
\hline 5 & & $x$ & & 31 & 10 & 0,00 & benar. \\
\hline 6 & & $x$ & & 99 & 33 & 0,00 & benar. \\
\hline 7 & & $x$ & & 31 & 10 & 0,00 & benar. \\
\hline 8 & & $x$ & & 22 & 7 & 0,00 & benar. \\
\hline 9 & & $x$ & & 68 & 22 & 0,00 & benar. \\
\hline 10 & & $x$ & & 43 & 14 & 0,00 & benar. \\
\hline 11 & & $\mathrm{x}$ & & 39 & 13 & 0,00 & benar. \\
\hline 12 & & $x$ & & 52 & 17 & 0,00 & benar. \\
\hline 13 & & $x$ & & 41 & 13 & 0,00 & benar. \\
\hline 14 & 0 & & & 45 & 15 & 0,00 & salah. \\
\hline 15 & & $\mathrm{x}$ & & 61 & 20 & 0,00 & benar. \\
\hline
\end{tabular}

Keterangan: Diterima $=0$ Ditolak $=\mathrm{x}$

Tabel 7 Data keseluruhan pengujian kelas 3 (8 minngu)

\begin{tabular}{|c|c|c|c|c|c|c|c|}
\hline \multirow[b]{2}{*}{$\begin{array}{l}\text { Data } \\
\text { yij }\end{array}$} & \multicolumn{3}{|c|}{ Kelas 3 (8 minggu) } & \multirow[b]{2}{*}{ epoch } & \multirow[b]{2}{*}{$\begin{array}{l}\text { wakty } \\
(\mathrm{s})\end{array}$} & \multirow[b]{2}{*}{ perfoma } & \multirow[b]{2}{*}{ Keterangang } \\
\hline & $\begin{array}{c}1 \\
\text { 4mingu }\end{array}$ & $\begin{array}{c}2 \\
3 \text { minggu }\end{array}$ & $\begin{array}{c}3 \\
\text { 8minngu } \\
\end{array}$ & & & & \\
\hline 1 & & & 0 & 20 & 6 & 0,00 & benar \\
\hline 2 & & & 0 & 31 & 10 & 0,00 & benar \\
\hline 3 & 0 & & & 36 & 12 & 0,27 & benar \\
\hline 4 & & & 0 & 71 & 23 & 0,00 & benar \\
\hline 5 & & & 0 & 31 & 10 & 0,00 & benar \\
\hline 6 & 0 & & & 29 & 9 & 0,00 & benar \\
\hline 7 & & & 0 & 80 & 26 & 0,00 & benar \\
\hline 8 & & & 0 & 17 & 5 & 0,00 & benar \\
\hline 9 & 0 & & & 64 & 21 & 0,00 & benar \\
\hline 10 & 0 & & & 38 & 12 & 0,00 & benar \\
\hline 11 & & & 0 & 34 & 11 & 0,00 & benar \\
\hline 12 & & $x$ & & 40 & 13 & 0,00 & salah \\
\hline 13 & 0 & & & 55 & 18 & 0,00 & benar \\
\hline 14 & 0 & & & 25 & 8 & 0,00 & benar \\
\hline 15 & & & 0 & 25 & 8 & 0,00 & benar. \\
\hline
\end{tabular}

Keterangan: Diterima $=0$ Ditolak $=\mathrm{x}$ 
Tahap yang perlu dilakukan adalah melakukan pengujian terhadap sistem klasifikasi tembakau oleh sensor gas yang akan ditampilkan pada aplikasi Delphi dan simpan hasil nilai grafik dalam pada MS.Excel untuk dicari dan dipilih data saat grafik stabil kurang lebih selama 10 menit. Setelah data didapat kemudian dijadikan data uji pada penulisan program Matlab. Metode learning vector quantization memiliki tingkat keakuratan $93,3 \%$ atau dengan tingkat eror $6.7 \%$ dari 45 pengujian.

\section{PENUTUP \\ 5.1 Kesimpulan}

Dari hasil pengujian alat dan haasil analisa dapat di buat beberapa kesimpulan sebagai berikut:

1. Pengunaan deret sensor semikonduktor dapat meningkatkan kehandalan dari system karena memiliki selektifitas yang lebih banyak.

2. Metode learning vector quantization di gunakan untuk mengklasifikasi aroma tembakau berumur 3 minggu, 4 minggu dan 8 mingu. Dengan tingkat keakuratan 93,3\% atau dengan tingkat eror $6.7 \%$ dari 45 pengujian.

3. Untuk waktu pengujian alat rata rata 10 menit untuk mendapatkan data yang stabil.

4. Dari pengujian alat waktu terbaik untuk pengambilan data adalah di pagi hari karena di waktu pagi aroma tembakau akan lebih pekat di banding dengan siang hari.

5. Penguji menggunakan varietas tanaman tembakau berjenis kelombo (asli dari temanggung).

\subsection{Saran}

Beberapa saran demi perbaikan dari penelitian ini sebagai berikut:

1. Kesing atau box sensor di sarankan untuk lebih kecil agar pembacaan gas lebih merata.

2. Gunakan udara referensi untuk sebagai base line agar data yang di peroleh lebih setabil.

3. Di sarankan pengambilan data uji di waktu pagi, siang dan malam agar untuk data latihnya lebih bisa menangkap data yang akurat.

\section{DAFTAR PUSTAKA}

Ardiansyah Fendi, Misbah, Pressa P. S.S. 2018. Sistem Monitoring Debu dan Karbon Monoksida Pada Lingkungan KerjanBoiler di PT. KARUNIA

ALAM SEGAR, Jurnal IKRA-ITH

Teknologi Vol 2 No 3 ISSN 2580-4308.

Fausett, L., 1994, Fundamentals of Neural Network:Architectures, Algorithms, and Applications,Prentice-Hall,Inc.,New

Jersey.

Figaro. 2004, "General Information for TGS 2600”, figarosensor.com

Kusumadewi, S.,2003.

ArtificialIntellegence (Teknik dan

Aplikasinya), Graha

Ilmu, Yogyakarta

QIN WANG Zheng-yin 1 and SHI Junxiong3.2007."Quality Charracteristics

of Tobacco Leaves with Different Aromatic Styles from Guizhou Prvince,

China". Agricultural Sciences in China 2007. 6(2): 220-226.

Rivai Muhammad, 2011. Klasifikasi Tembakau Menggunakan Deret Sensor

Tin-Oxide dan Neural Network, JAVA Journal of ElektronicsEngineering, Vol. 9, No.2,2011.

Tirtosastron Samsuri, A. S. Murdiyati, 2010. Kandungan Kimia Tembakau dan
Rokok.
Buletin
Tanaman

tembakau,Serat dan Minyak Industri2 (1). 33 34 ISSN 2085-6717. 